\title{
Anno Domini 2000 or Woman's Destiny
}

Julius Vogel. Introduction by Roger Robinson.

Auckland, Exisle Publishing Limited, 2000. Pp.184;

NZ\$29.95 (paperback).

In 1889 Sir Julius Vogel, former Prime Minister of New Zealand, published a utopian/science fiction novel entitled Anno Domini 2000 or Woman's Destiny. One hundred and eleven years later Roger Robinson, Professor of English at Victoria University of Wellington, has written a critical introduction to a timely new publication of Vogel's original piece. As Robinson states, not only is this republication justified on account of Vogel's uncannily accurate future predictions, but also because it has an important place in the history of Utopian, science fiction and New Zealand literature that merits further attention. The first half of the novel surrounds the adventures of its young, female, New Zealand protagonist Hilda Richmond Fitzherbert, who works bravely to preserve the integrity of a future British empire. The second half, which sees a future war between the British and American empires, ends with Hilda's marriage to the emperor, a superlative British victory, and the 'New English States' rejoining the British empire

Robinson states that Vogel's 'prophecy of the future... came nearer the mark than George Orwell's...' (11), supporting this claim by emphasising: Vogel's vision of a prosperous independent Ireland; an Australian republican movement; a united Europe; air travel in the form of cruisers powered by revolving fans; and the widespread use of electricity and home air-conditioning. In addition to highlighting Vogel's role as the Nostradamus of New Zealand, Anno Domini 2000 is also of interest for its place in the history of New Zealand Utopian and science fiction literature, genres which include not only the more well-known names like Trollope, Verne and Butler but even those not so well-known such as Bell, Brown and 'The Inhabitant'. While such a Utopian tradition appears to mirror a common late nineteenth century literary response to the evils of the 'Gilded Age' and industrialisation (evident in the work of Bellamy and Morris), it also seems to have arisen independently as a result of the country's island geography and late settlement. This distinctive New Zealand Utopian vein, as Robinson attests, is additionally prevalent in a great deal of the colony's promotional literature.

In the Introduction Robinson states that 'It is not unusual for the authors of Utopias to use their fictional story mainly as a framework for their arguments.'

Kōtare 4, no. 1 (2001), pp. 73-85. 
(21) This is certainly the case with Anno Domini 2000. Nowhere are Vogel's particular political beliefs more evident than with the issue of female equality and the righteousness of the British Empire. Throughout the text, women are consequently seen to enjoy the highest of political positions: Hilda at 22 has already been elected to the Imperial Federal Parliament and the Prime Minister of the Empire and Leader of the Opposition are both women (a startling parallel to contemporary New Zealand politics). The other dominant theme of the novel is the paramountcy of the British Empire and Vogel's vision of a federation of self-governing dominions, a rotating imperial Parliament, and an imperial army numbering millions.

Robinson presents an excellent critical Introduction to the novel, highlighting all of the above and providing a beautifully crafted commentary on the work's style. One wonders, nevertheless, whether the Introduction in places seems somewhat brief? It might have been useful to extend the discussion of female equality, for despite the novel's feminist position all the central female characters are married off by the conclusion, rendering the piece somewhat traditional in its ending - a happy multiple wedding in the manner of $A$ Midsummer Night's Dream. The question of race also deserves further comment. Robinson, drawing attention to the work's penultimate paragraph, states that Vogel is apparently oblivious to the plight of the colonised. There are, however, further echoes elsewhere of this ethnocentric world view, evident with the four powers of this future earth all being white and with the male protagonists reading like standard Boys Own heroic characters. The emperor himself is described as a young, handsome 'Saxon-type' (51). Yet Vogel's vision of the Other is not an entirely negative one either. Good relations exist with the friendly, if unsophisticated, 'Antarctic Esquimaux' (119) and a number of prominent Jewish heroes pepper the text.

Anno Domini 2000 invites further comparisons with other Utopian works too. How does Vogel's future female vision differ from other feminist Utopias such as Herland and from other socialist Utopias such as Looking Backward? Where does Vogel's vision of a future British Empire sit with other similar texts? A rotating imperial capital, for instance, is the subject of Edwin Harrow's New Zealand as I have found it (1890), while ideas of a federated empire had appeared in Wellington in The Federation of the British Empire (1880). It might have also been an interesting exercise to suggest similarities between Vogel's personal life and developments in the novel. Why does Vogel, for example, emphasise such prominent Jewish characters? Was it a means to counter the anti-Semitism which he had experienced during his lifetime and to show that Jews could be trusted members of the empire? How does this pro-Jewish

Kōtare 4, no. 1 (2001), pp. 73-85. 
position differ from other more anti-Semitic science fiction works of the time? Why was Vogel so pro-Ireland? Was it out of sympathy for a nationalist cause, empathy for a people similarly stereotyped like the Jews, or both? Interestingly enough, while Vogel remains very pro-British, he also appears to demonstrate a strong sense of colonial proto-nationalism, evident in the empire's Dominions forcing [my italics] Britain to accept Irish self-government and with urban Londoners being depicted on 'the verge of effeminacy' vis a vis the inhabitants of the new world (137). Such a contrast between Britain and the colonies is again very reminiscent of turn-of-the-century booster publications where the inhabitants of New Zealand are often described as 'the best of the British'.

Despite the novel's sometimes slow pace and contrived dialogue there are a variety of factors which make Anno Domini 2000 deserving of further study. Indeed, this text would make a great addition to any undergraduate course in nineteenth century New Zealand literature, particularly with its themes of gender, race, and nationalism, not to mention technological developments, future wars, and even a lost civilisation in the Antarctic. Combined with the new publication's beautiful print quality and updated typeset, as well as the clever use of the attractive 1940 Centennial Exhibition Certificate as a cover (which draws attention to the forward march of women and the contrast between the past/ future and old world/new world), Robinson has done a great service to draw our attention to this most interesting work in an often neglected genre.

Dominic Alessio is a Lecturer in History at Richmond, The American International University in London.

\section{Magnitude Eight Plus: New Zealand's Biggest Earthquake.}

Rodney Grapes.

Wellington: Victoria University Press, 2000.

Living in New Zealand means living with earthquakes, and many New Zealanders are intensely interested in 'the big one'. Every time they feel the ground move they are eager for information on the earthquake's magnitude and location. A recent moderate magnitude (6.3), deep earthquake in the central North Island resulted in 105,000 hits on the Institute of Geological \& Nuclear Sciences website during the following day.

Kōtare 4, no. 1 (2001), pp. 73-85. 